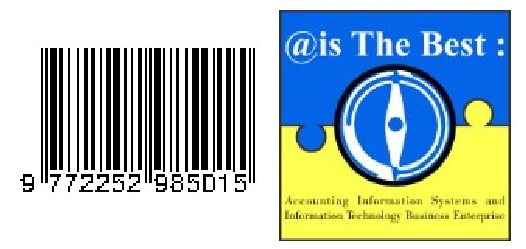

Volume 01, Nomor 01

April 2012

P-ISSN: 2252-9853

DOI :

E-ISSN:

\title{
PERANCANGAN SISTEM INFORMASI AKUNTANSI DENGAN METODE DECISION SUPPORT SYSTEM (DSS)
}

\author{
Dony Waluya Firdaus ${ }^{1)}$, Lina Roslina ${ }^{2)}$, Hery Dwi Yulianto ${ }^{3)}$ \\ Program Studi Komputerisasi Akuntansi \\ Fakultas Teknik dan Ilmu Komputer \\ Universitas Komputer Indonesia \\ dony_waluya@yahoo.com ${ }^{1)}$, cutelinz@rocketmail.com ${ }^{2)}$, denderpete@yahoo.com ${ }^{3)}$
}

\section{ABSTRACT}

The research was conducted at PT. Sinkona Indonesia Lestari is a manufacturing company engaged in the industry that produces quinine salt of quinine and its derivatives. The Company requires cash flow of financial statements information that is fast, precise, accurate and up to date for management decision making. Authors are interested with the title "Accounting Information System Design Method With Decision Support System (DSS").

Design studies using primary data and secondary data, system development methodology using output oriented methodology, process oriented methodology and the data oriented methodology. While the structure of system development used by the authors is Waterfall. Accounting information system design using a context diagram, data flow diagrams, system flowcharts, and Entity Relationship Diagram. With accounting information systems managers can improve the quality of decision making.

Keywords: Accounting Information Systems, Decision Support System (DSS). 


\section{Jurnal Riset Komputerisasi Akuntansi \\ @is The Best, Vol. 1, No. 1, April 2012: Hal. 61-80}

\section{PENDAHULUAN}

\section{Latar Belakang}

Seiring dengan makin berkembangnya tuntutan dunia bisnis dan telah bergesernya paradigma bisnis dari Comparative Advantage menjadi Competitive Adventage, perusahaan selaku pelaku bisnis dituntut untuk dapat terus mengembangkan inovasi dan mengasah intuisinya untuk mencapai tujuan. Tujuan perusahaan pada saat ini adalah lebih mengarah kepada customer profitability, yang berarti bahwa perusahaan berusaha untuk menciptakan nilai bagi konsumen yang juga akan berakibat menghasilkan nilai pula bagi perusahaan yang seharusnya didukung oleh teknologi dan sistem informasi. Sistem informasi merupakan salah satu sub sistem organisasi untuk mengelola informasi. Saat ini sistem informasi dioperasikan oleh hampir seluruh sumber daya manusia suatu organisasi sehingga tidak dapat dipisahkan dengan operasi dan kehidupan organisasi. Saat ini dan dimasa mendatang perhatian terhadap informasi akan terus meningkat, salah satu hal ini disebabkan semakin tingginya kemampuan komputer (Azhar Susanto 2007).

Kegiatan pembuatan laporan keuangan merupakan aspek terpenting di perusahaan-perusahaan ataupun di instansi pemerintahan, karena tiap penerimaan dan pengeluaran kas yang dilakukan oleh perusahaan harus dibuatkan laporannya untuk pengambilan keputusan. Sebuah perusahaan membutuhkan sistem informasi akuntansi karena sistem informasi akuntansi merupakan sebuah sistem yang memproses data untuk menghasilkan suatu informasi keuangan yang cepat, tepat, akurat dan up to date sebagai dasar dalam pengambilan keputusan. Untuk melakukan peran-peran tersebut, para manajer memerlukan informasi yang dikirim secaraa efisien dan dalam cara yang dibatasi oleh waktu, ke komputer manajer didalam desktop, ke komputer mobile dan bahkan ke komputer embedded pada PDA dan telepon seluler. Informasi ini dikirim oleh komputer yang berfungsi sebagai server. Para manajer juga menggunakan komputer untuk mendukung dan meningkatkan pengambilan keputusan (Turban dkk. 2005).

Objek penelitian ini dilakukan di PT. Sinkona Indonesia Lestari, merupakan perusahaan manufaktur yang bergerak di bidang industri kina yang menghasilkan garam kina beserta turunannya, sebagai salah satu pelaku ekonomi, dalam setiap aktivitasnya harus mencatat setiap penerimaan dan pengeluaran kas perusahaan. Proses pencatatan transaksi keuangan arus kas pada PT. Sinkona Indonesia Lestari sudah terkomputerisasi yaitu menggunakan lotus dimana lotus disini sudah link antar sheet, namun sofware yang digunakan perlu di upgrade, karena selain waktu yang lama dalam proses pembuatan laporan lotus juga kurang efektif dan efisien. Lotus tidak bisa terintegrasi dengan jaringan, untuk itu software yang ada perlu di upgrade agar informasi dapat diperoleh secara cepat, tepat dan akurat dan waktu yang digunakan lebih efektif dan efisien. Sedangkan untuk proses pencatatan kas masuk dan kas keluar belum memenuhi standar akuntansi, dimana proses pencatatan yang ada disana yaitu dimulai dari jurnal memorial, kartu rekening bukubesardan laporan pertanggungjawaban keuangan. Bila ada penerimaan atau pengeluaran kas dicatat ke dalam jurnal memorial dan diposting ke kartu rekening buku besar untuk menghasilkan keluaran yaitu laporan pertanggungjawaban keuangan. Pada saat melaksanakan kegiatan pencatatan laporan kas masuk dan kas keluar. 


\section{Jurnal Riset Komputerisasi Akuntansi \\ @is The Best, Vol. 1, No. 1, April 2012: Hal. 61-80}

Perancangan Sistem Informasi Akuntansi menggunakan software Microsoft Visual Basic 6.0 dan SQL Server 2000 sebagai databasenya. Alasan Penulis menggunakan kedua software tersebut adalah karena Microsoft Visual Basic 6.0 lebih terstruktur dalam bentuk pemrogramannya, maka dari itu penulis menambahkan software lain untuk pembuatan databasenya, yaitu SQL Server. Penulis juga akan menggunakan Crystal Report untuk tampilan laporan keuangan, karena Crystal Report merupakan program khusus untuk membuat laporan yang terpisah dari program Microsoft Visual Basic 6.0, tetapi keduanya dapat diintegrasikan secara harmonis.

\section{Rumusan Masalah}

Inti kajian penelitian ini adalah mengenai Sistem Informasi Akuntansi dengan metode decision support system (DSS). Masalah ini merupakan merupakan kekuatan yang perlu dikembangkan untuk meningkatkan mutu pengambilan keputusan oleh manajer.

A. Apakah sistem informasi akuntansi dapat menghasilkan laporan keuangan yang cepat, tepat, akurat dan up to date.

B. Apakah sistem informasi akuntansi dapat meningkatkan mutu pengambilan keputusan.

\section{Batasan Masalah}

Mengingat luasnya lingkup kegiatan di PT. Sinkona Indonesia Lestari, maka diberikan batasan masalah penelitian sebagai berikut:

A. Laporan keuangan yang akan dirancang di sistem informasi akuntansi adalah laporan keuangan arus kas. Penerimaan kas diperoleh dari penjualan dan penanaman modal sedangkan pengeluaran kas untuk pembayaran beban-beban perusahaan, pembelian peralatan dan perlengkapan kantor, pembelian bahan baku dan bahan penolong.

B. Perancangan sistem informasi akuntansi laporan keuangan arus kas menggunakan software Micrososft Visual Basic 6.0 dan SQL Server 2000 sebagai databasenya.

\section{Tujuan Penelitian}

Tujuan dari penelitian ini adalah:

A. Sistem informasi akuntansi dapat menyelesaikan masalah-masalah yang dihadapi PT. Sinkona Indonesia Lestari dan untuk mendukung proses pengambilan keputusan oleh manajemen.

B. Mempermudah proses pengambilan keputusan dengan menyediakan informasi laporan keuangan laporan arus kas dan laporan pendukung lainnya.

\section{KERANGKA TEORITIS}

\section{Perancangan}

Menurut AL-Bahradalam bukunya yang berjudul Analisis dan Desain Sistem Informasi yang dimaksud dengan Perancangan adalah sebagai berikut:"Perancangan (design) memiliki tujuan untuk mendesain sistem baru yang dapat menyelesaikan masalah-masalah yang dihadapi perusahaan yang diperoleh dari pemilihan alternatif sistem yang terbaik.” (2005:39)

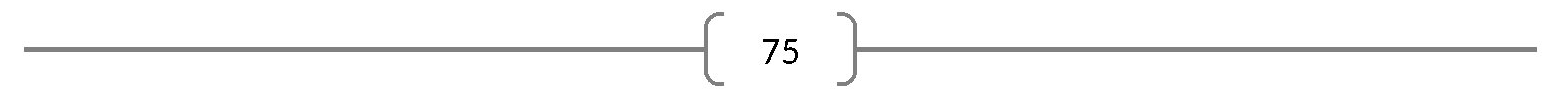




\section{Sistem}

Berikut ini dikemukakan pendapat dari pakar mengenai pengertian sistem, akan penulis uraikan seperti yang diungkapkan oleh Popa et.al (2008) bahwa :

"Sebuah sistem merupakan seperangkat unsur bergantung membentuk kesatuan entitas tunggal. Suatu jenis tertentu dari sistem adalah salah satu ekonomi yang mendefinisikan komponen ekonomi dan mekanisme seperti perusahaan, industri, sebuah bidang ekonomi nasional dan sebagainya. Bahkan ekonomi nasional dan di seluruh dunia dapat dilihat pada tingkat ekonomi global sebagai sistem ekonomi yang kompleks".

Popa et.al (2008), menerangkan bahwa komponen dari sebuah sistem, sebagai berikut :

1. Inputs;

2. Outputs;

3. Transformation process;

4. System structure and its state.

Sebuah sistem ekonomi yang rumit seperti Gambar 2.1 The Components Of An Economic System, dimana komponen - komponen tersebut adalah :

1. Decision system;

2. Operating system;

3. Information system.

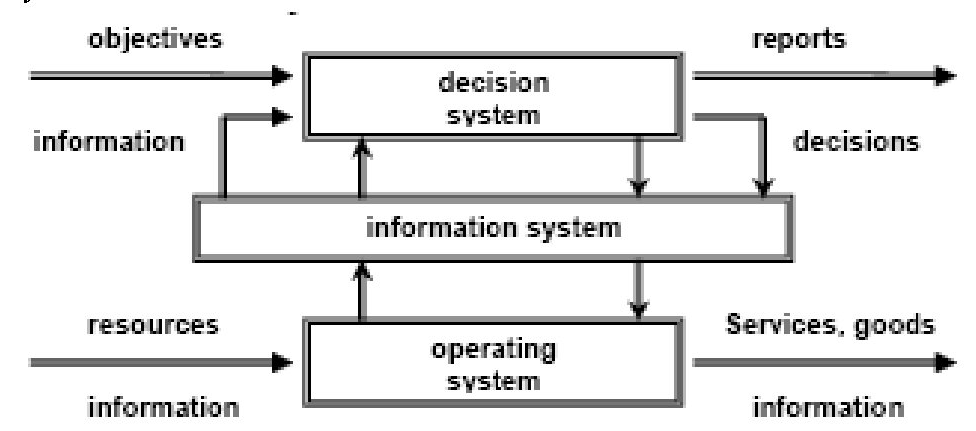

Gambar 1.The Components Of An Economic System

Sumber: Popa et.al (2008)

Menurut Azhar Susanto (2007) definisi sistem adalah :

"Sistem adalah kumpulan/group dari sub sistem/bagian/komponen apapun baik phisik atau pun non phisik yang saling berhubungan satu sama lain dan bekerja sama secara harmonis untuk mencapai satu tujuan tertentu".

Dari pembahasan sistem tersebut dapat sistem digambarkan dengan menentukan komponenkomponennya. Bagaimana komponen-komponen sistem tersebut berhubungan satu sama lain serta bekerja sama dalam mencapai tujuannya. Perusahaan terdiri dari komponen orang - orang, divisi divisi, bangunan, mesin dan peralatan yang semuanya berhubungan satu sama lain, bekerja sama secara harmonis dalam melaksanakan aktivitas untuk mencapai tujuan perusahaan.

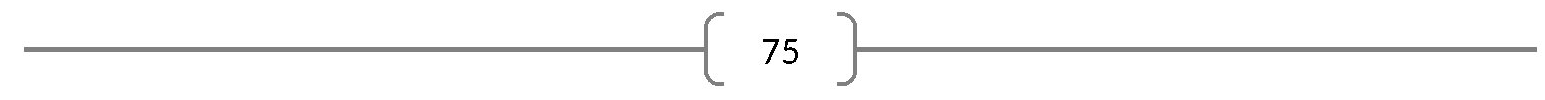




\section{Jurnal Riset Komputerisasi Akuntansi}

\section{@is The Best, Vol. 1, No. 1, April 2012: Hal. 61-80}

Sistem memiliki beberapa ciri, yaitu tujuan sistem, batas sistem, sub sistem, hubungan sistem serta hirarki sistem, input - proses - output, serta lingkungan sistem (lingkugnan iternal dan eksternal). Ciri - ciri atau kriteria dapat digunakan sebagai tolak ukur dalam menilai keberhasilan suatu sistem dan menjadi dasar dilakukannya suatu pengendalian.

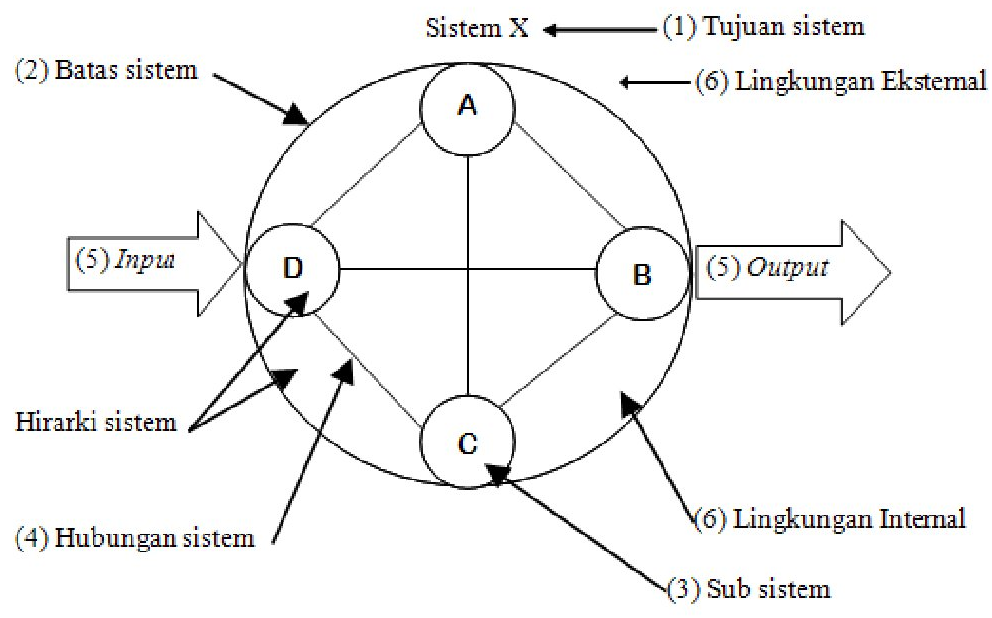

Gambar 2. Ciri - Ciri Sistem

Sumber : Azhar Susanto (2007)

\section{Informasi}

Data adalah fakta atau apapun yang dapat digunakan sebagai input dalam menghasilkan informasi. Kita harus mengetahui terlebih dahulu informasi mengenai data apa saja yang dibutuhkan, jangan sampai banyak data yang tidak memberikan kontribusi dalam pemrosesannya menjadi informasi. Jadi dapat dikatakan bahwa informasi adalah hasil dari pengolahan data, akan tetapi tidak semua hasil dari pengolahan tersebut bisa menjadi informasi, hanya hasil pengolahan data yang memberikan arti dan manfaat saja. Azhar (2007) mengemukakan, "Informasi merupakan hasil dari pengolahan data, yang memberikan arti dan manfaat".

Informasi akan memberikan arti dan manfaat bila memenuhi karakteristik kualitatif tertentu. Azhar Susanto (2007) dalam Mc Leod (2004) mengatakan bahwa Informasi yang berkualitas harus memiliki ciri-ciri sebagai berikut :

1. Akurat

Artinya, Informasi harus mencerminkan keadaan yang sebenarnya.

2. Tepat waktu

Artinya, Informasi tersebut tersedia atau ada pada saat informasi tersebut diperlukan.

3. Relevan

Artinya, Informasi yang diberikan harus sesuai yang dibutuhkan.

4. Lengkap

Artinya, Informasi harus diberikan secara lengkap.

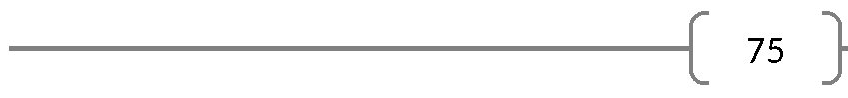




\section{Jurnal Riset Komputerisasi Akuntansi \\ @is The Best, Vol. 1, No. 1, April 2012: Hal. 61-80}

\section{Akuntansi}

Definisi Akuntansi menurut Bastian Indra dalam bukunya yang berjudul Sistem Akuntansi Sektor Publik, menyebutkan bahwa: "Akuntansi adalah proses pencatatan, penggolongan, pemeriksaan dan penyajian dengan cara-cara tertentu, transaksi keuangan yang terjadi dalam perusahaan atau organisasi lain serta penafsiran terhadap hasilnya."(2003:2)

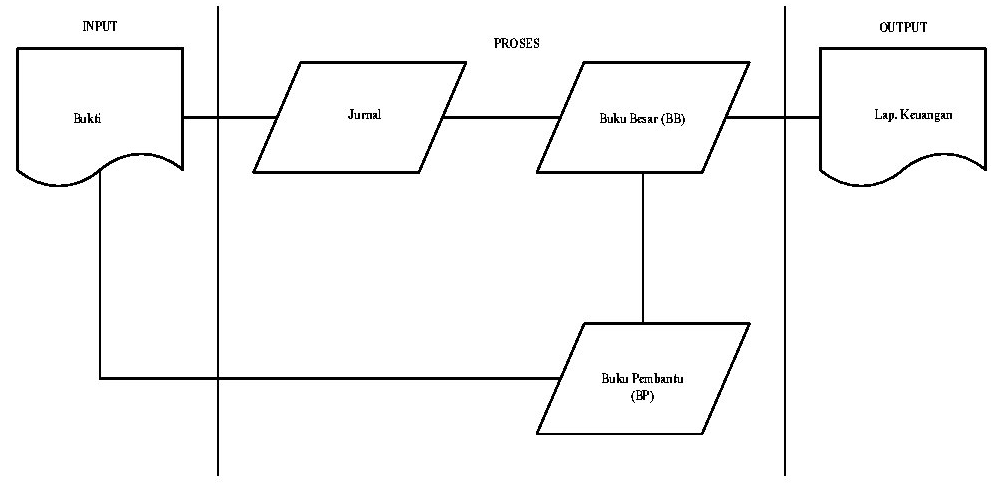

Gambar 3. Proses Akuntansi

\section{Sistem Informasi}

Azhar Susanto (2007) mengemukakan bahwa "Sistem Informasi didefinisikan sebagai kumpulan dari sub-sub sistem baik phisik maupun non phisik yang saling berhubungan satu sama lain dan bekerja sama secara harmonis untuk mencapai satu tujuan, yaitu mengolah data menjadi informasi yang berguna".

Menurut Bodnar et.al (2006) bahwa sistem informasi menyiratkan penggunaan teknologi komputer dalam suatu organisasi untuk menyediakan informasi bagi pengguna. Sistem informasi berbasis komputer merupakan satu rangkaian perangkat keras dan perangkat lunak yang dirancang untuk mentransformasikan data menjadi informasi yang berguna. Beberapa tipe sistem informasi yang memanfaatkan komputer yaitu EDP (Electronic Data Processing) (sistem pengolahan data elektronik), DP (Data Processing) (sistem pemrosesan data), MIS (Management Information System) (sistem informasi manajemen), DSS (sistem pendukung keputusan), ES (sistem pakar), EIS (sistem informasi eksekutif), AIS (Accounting Information System) (sistem informasi akuntansi). Sistem informasi sebagai integrasi suatu cara terorganisir (mengumpulkan, memasukkan, dan memroses data, mengendalikan, dan menghasilkan informasi) dengan berbasis komputer untuk mencapai sasaran dan tujuan organisasi. Sistem Informasi mengolah data menjadi informasi dengan menggunakan alat. Alat pengolahan data menjadi informasi ini terus menerus mengalami perkembangan. Komputer muncul sebagai sebagai alat pengolah data. Sistem yang menggunakan komputer sebagai alat pengolah disebut sistem informasi. Sistem Informasi memiliki beberapa komponen yang dikelompokan kedalam hardware, software, brainware, procedure, database, dan jaringan komunikasi. (Azhar, 2007). 


\section{Jurnal Riset Komputerisasi Akuntansi \\ @is The Best, Vol. 1, No. 1, April 2012: Hal. 61-80}

\section{Laporan Arus Kas}

Definisi Laporan arus kas menurut Halim Abdul dalam bukunya yang berjudul Akuntansi Sektor Publik-Akuntansi Keuangan Daerah, adalah sebagai berikut: "Laporan ini menyajikan informasi mengenai penerimaan dan pengeluaran kas yang berkaitan dengan aktivitas operasi, investasi dan pembiayaan." (2004:64)

\section{METODE PENELITIAN}

\section{Unit Analisis}

Menurut Sarwono Jonathan dalam bukunya Riset Bisnis menjelaskan bahwa: "Unit analisis adalah obyek yang perilakunya akan dianalisa atau disebut juga dengan variabel dependen."(2008:79)

Menurut Prijana mendeskripsikan dalam bukunya Metode Sampling Terapan unit analisis sebagai berikut: "Unit analisis adalah organisasi, kelompok orang, kejadian, atau hal-hal lain yang dijadikan objek penelitian dalam satuan tertentu yang diperhitungkan dalam subjek penelitian." $(2005: 107)$

Penulis melakukan pengumpulan data yang berkaitan dengan sistem informasi laporan keuangan arus kas pada bagian keuangan pada PT. Sinkona Indonesia Lestari Subang yang bergerak di bidang industri garam kina untuk kemudian dianalisis untuk pengambilan kesimpulannya. Unit analisisnya adalah yang menjadi objek penelitian yaitu sistem informasi laporan keuangan arus kas.

\section{Populasi dan Sampel}

Menurut Nazir M dalam bukunya yang berjudul Metode Penelitianmenjelaskan bahwa: "Populasi adalah kumpulan dari individu dengan kualitas serta ciri-ciri yang telah ditetapkan."(2005 : 271). Menurut Nazir Mdalam bukunya Metode Penelitianmenjelaskan bahwa: "Sampel adalah bagian dari populasi." (2005:271)

Menurut HMJogiyanto dalam bukunya yang berjudul Analisis dan Desain Sistem Informasi menjelaskan bahwa: "Populasi adalah seluruh item yang ada disebut dengan universe atau populasi (population)." (2005 : 631). Menurut HMJogiyantodalam bukunya yang berjudul Analisis dan Desain Sistem Informasi menjelaskan bahwa: "Sampel adalah sebagian item yang dipilih disebut dengan sampel-sampel (samples)." (2005: 631)

Penulis mengambil populasi perusahaan manufaktur yang bergerak di bidang industri kina yaitu PT. Sinkona Indonesia Lestari Subang. Sampel yang penulis gunakan adalah sampel nonprobabilitas yaitu kesimpulan yang ditarik dari populasi tidak dapat digeneralisasikan kepada seluruh populasi dan besar peluang anggota populasi untuk terpilih sampel tidak diketahui. Sampel yang dipilih adalah bagian-bagian yang terkait dengan penerimaan dan pengeluaran kas perusahaan yaitu seksi tata usaha keuangan, seksi akuntansi, seksi penjualan, seksi pengadaan, dan bagian umum/sdm. 


\section{Rekayasa Perangkat Lunak}

\section{Metodologi Pengembangan Sistem}

Menurut HMJogiyantodalam bukunya Analisis dan Desain Sistem Informasi menjelaskan bahwa: "Metodologi Pengembangan Sistem adalah metode-metode, prosedur-prosedur, konsepkonsep pekerjaan, aturan-aturan dan postulat-postulat yang akan digunakan untuk mengembangkan suatu sistem informasi."(2005:59)

Menurut SutabriTata dalam buku Analisis Sistem Informasi menjelaskan bahwa: "Metodologi Pengembangan Sistem adalah metode-metode, prosedur-prosedur, konsep-konsep pekerjaan dan aturan-aturan untuk mengembangkan suatu sistem informasi."(2003:68)

Adapun Metodologi Pengembangan Sistem yang digunakan oleh penulis yaitu metodologi yang berorientasi pada keluaran, proses, dan data. MenurutSutabri Tata dalam buku Analisis Sistem Informasi menjelaskan bahwa:

\section{A. Metodologi yang berorientasikan keluaran (output)}

Metodologi inidisebut juga dengan metodologi tradisional. Diperkenalkan sekitar tahun 1960 dengan memberikan tahapan dalam pengembangan sistem tanpa dibekali dengan teknik dan piranti yang memadai. Fokus utama metodologi ini adalah pada keluaran/output sepertilaporan penjualan, laporan pembelian, dan lain sebagainya.

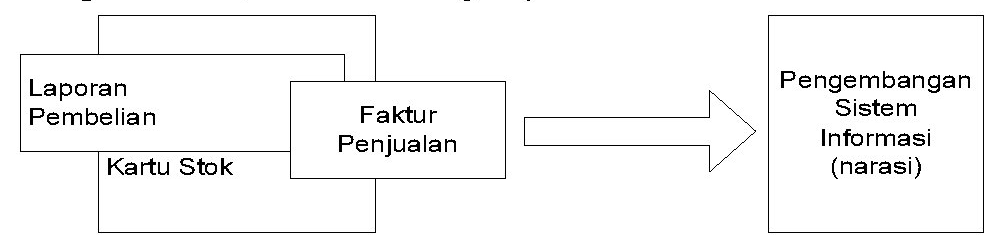

Gambar 4. Metodologi yang berorientasi pada keluaran (output) (2003:69)

\section{B. Metodologi yang berorientasikan proses}

Metodologi yang berorientasikan proses disebut juga dengan metodologi struktur analisis dan desain. Metode ini telah dilengkapi dengan alat-alat (Tool) seperti Data Flow Diagram (DFD), bagan terstruktur dan kamus data dan teknik-teknik yang dibutuhkan untuk pengembangan sistem, khususnya pemrograman terstruktur atau modular. Fokus utama metodologi ini pada proses dengan menggambarkan dunia nyata yang memakai data flow diagram.
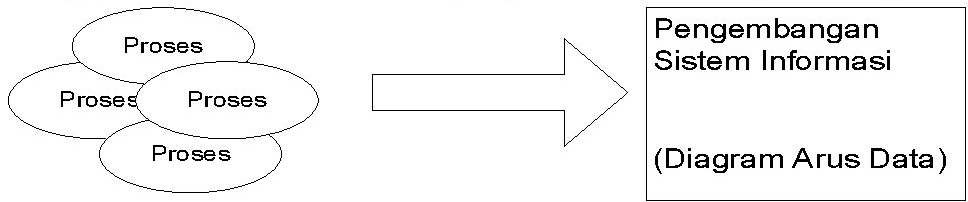

Gambar 5. Metodologi yang berorientasikan proses. (2003:70)

\section{Metodologi yang berorientasikan data}

Metodologi ini disebut juga metodologi model informasi, diperkenalkan sekitar tahun 1980 dengan semakin banyaknya perusahaan yang menggunakan Relation Database Management System. Alat yang digunakan untuk membuat model adalah Entity Relational Diagram (ERD).

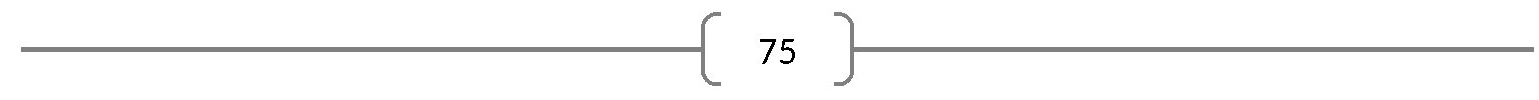




\section{Jurnal Riset Komputerisasi Akuntansi}

\section{@is The Best, Vol. 1, No. 1, April 2012: Hal. 61-80}

Fokus utama metodologi ini adalah data, dimana dunia nyata digambarkan dalam bentuk entitas, atribut data serta hubungan antar data tersebut.
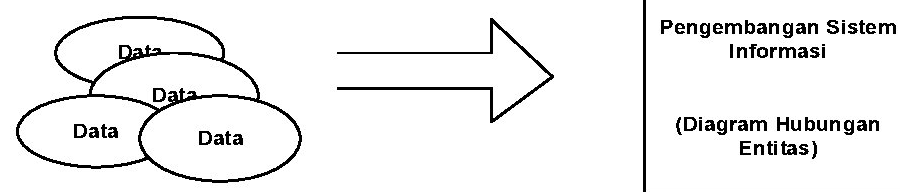

Gambar 6. Data Sebagai Fokus Utama (2003:71)

Penulis menggunakan tiga metodologi pengembangan sistem dalam perancangan sistem informasi akuntansi laporan arus kas yaitu metodologi yang berorintasikan keluaran, proses dan data. karena penulis akan membuat sebuah program yang akan menghasilkan sebuah keluaran berupa laporan keuangan arus kas, maka penulis perlu ketiga metodologi tersebut agar data diperoleh secara cepat, tepat, dan akurat.

\section{Model Pengembangan Sistem}

Struktur pengembangan sistem yang digunakan oleh penulis adalah Waterfall, yaitu setiap tahap harus diselasaikan terlebih dahulu secara penuh sebelum diteruskan ke tahap berikutnya untuk menghindari terjadinya pengulangan tahapan. Penulis menggunakan cara Waterfall karena dilakukan secara bertahap. Perancangan sistem informasi akuntansi laporan arus kas pada PT. Sinkona Indonesia Lestari Subang akan sangat baik jika semua tahapannya dilakukan secara penuh untuk mempermudah pemakainya (user-nya) dalam menggunakan sistem yang baru.

Menurut Sutabri Tata dalam bukunya yang berjudul Analisa Sistem Informasiadalah sebagai berikut:

"Penerapan tahapan pengembangan sistem informasi dengan cara Waterfall adalahdimana setiap tahap harus diselesaikan terlebih dahulu secara penuh sebelum diteruskan ke tahap berikutnya untuk menghindari terjadinya pengulangan tahapan."(2003:62)

Pengembangan sistem informasi akuntansi laporan arus kas yang dibuat harus dilakukan secara bertahap, dimana tahapan-tahapan tersebut dilakukan sesuai prosedur sehingga pelaksanaannya harus dilakukan secara berurutan dan terstruktur agar tidak terjadi pengulangan tahapan apabila terjadi kesalahan.

Struktur Pengembangan sistem Waterfall dapat dilihat pada gambar 1.4 dibawah ini:

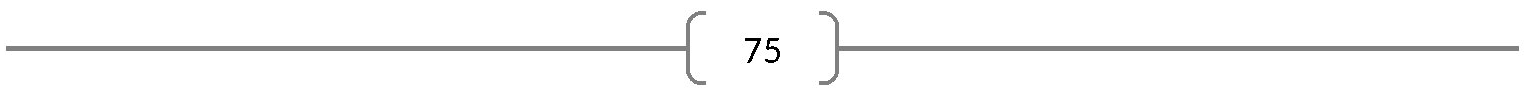




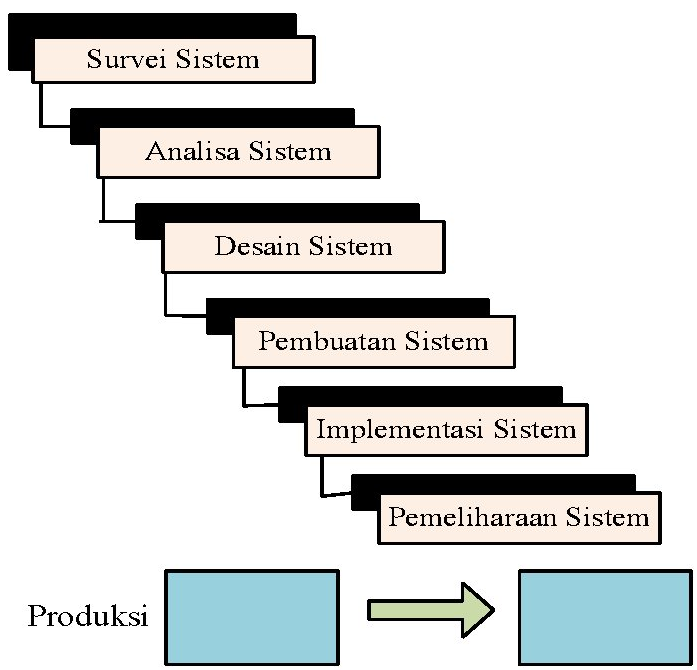

Gambar 7. Struktur Pengembangan Sistem Waterfall (2003:62)

Penulis memilih struktur pengembangan sistem tersebut karena dalam proses perancangan sistem informasi akuntansi laporan keuangan arus kas dilakukan secara bertahap dimana pada setiap tahapan dilakukan sesuai prosedur sehingga pelaksanaannya harus secara berurutan.

\section{ANALIS DATA}

Struktur Organisasi Yang Berjalan adalah sebagai berikut:

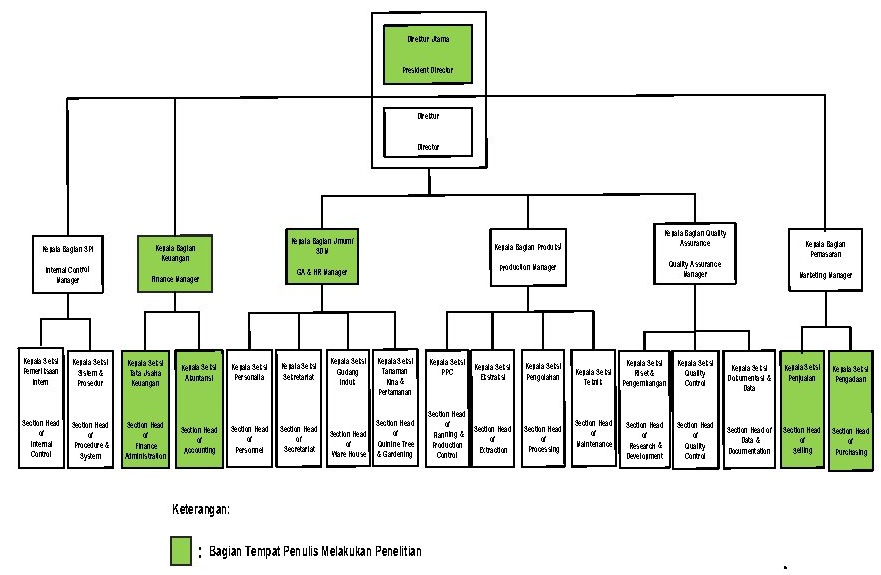

Gambar 8. Struktur Organisasi yang Berjalan

\subsection{Diagram Konteks yang Berjalan}




\section{Jurnal Riset Komputerisasi Akuntansi}

\section{@is The Best, Vol. 1, No. 1, April 2012: Hal. 61-80}

1. Diagram Konteks

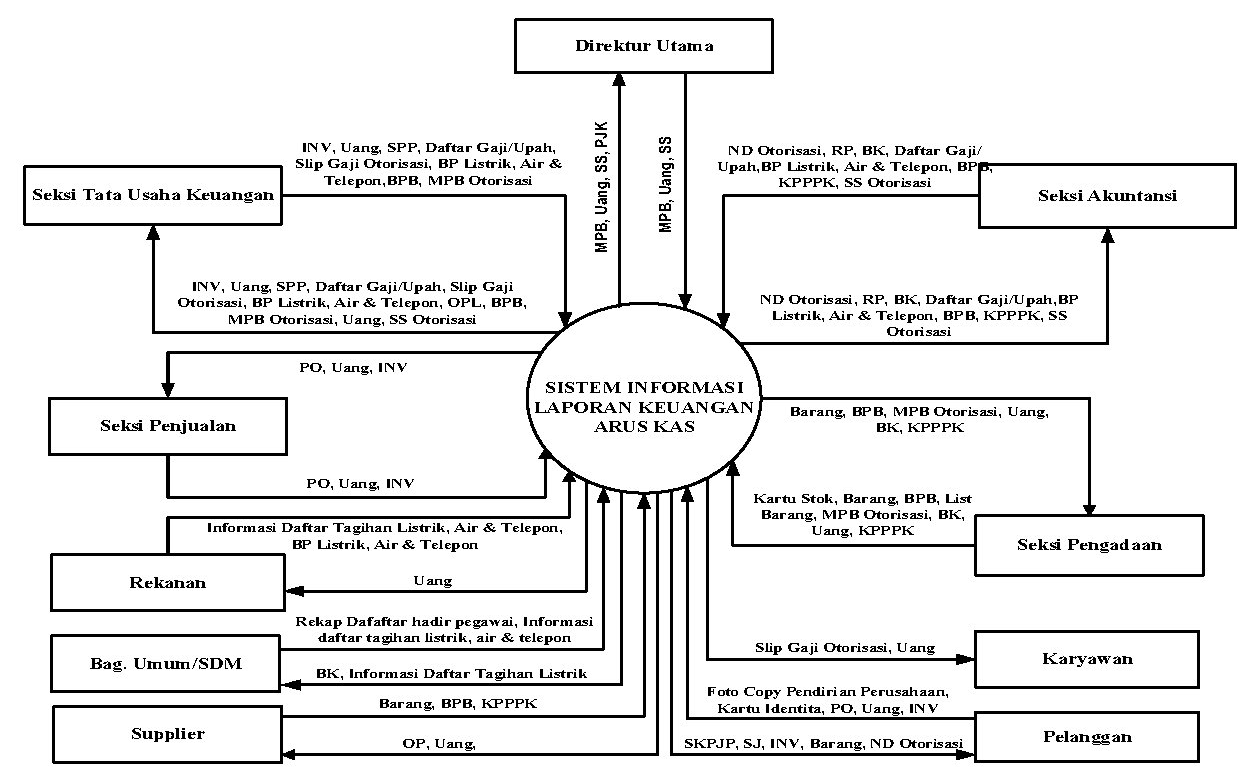

Gambar 9. Diagram Konteks Berjalan

2. Data Flow Diagram (Diagram Alur Data) Level 1Yang Berjalan

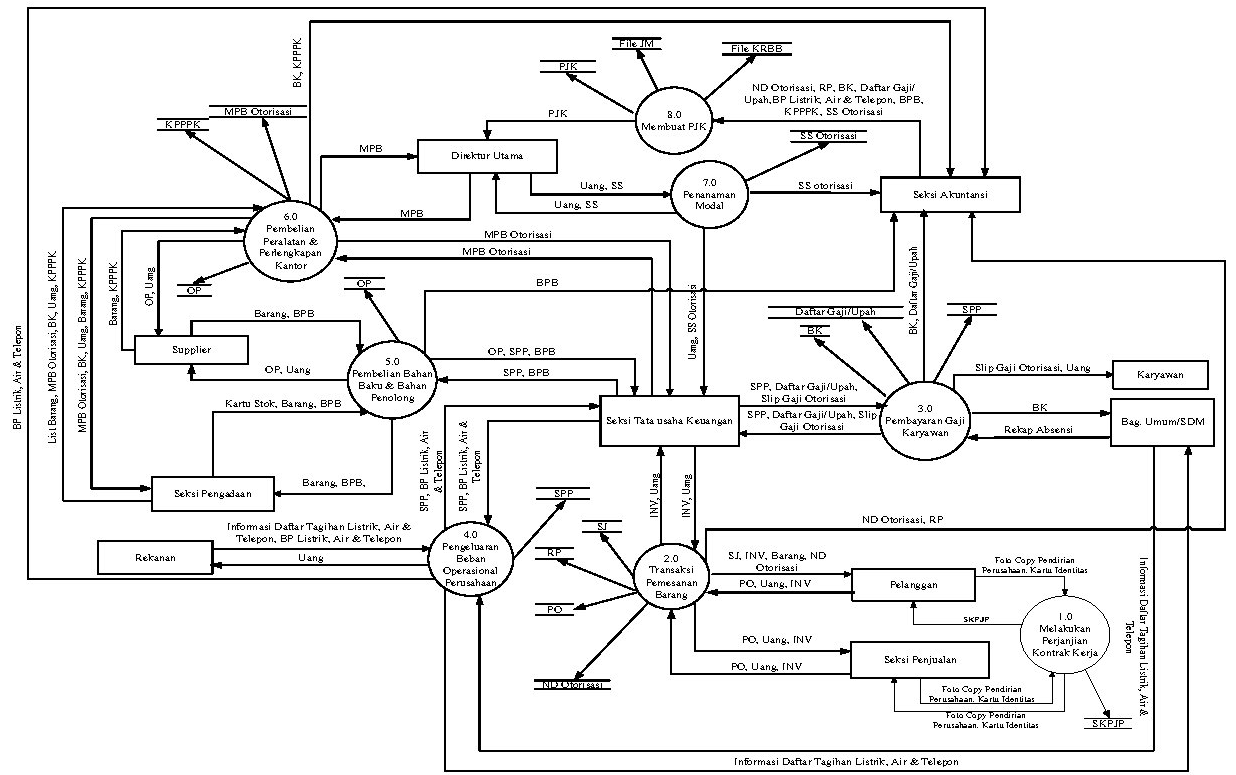

Gambar 10. Data Flow Diagram Level 0 Yang Berjalan

\section{PEMBAHASAN}

Perancangan Sistem Informasi Akuntansi Dengan Metode Pengambilan Keputusan

\subsection{Sistem Informasi Akuntansi Yang Diusulkan}




\section{Jurnal Riset Komputerisasi Akuntansi}

\section{@is The Best, Vol. 1, No. 1, April 2012: Hal. 61-80}

A. Account Name dan Code Account yang Diusulkan

Tabel 1. Tabel Account dan Code Account

\begin{tabular}{|l|c|}
\hline \multicolumn{1}{|c|}{ Account Name } & $\begin{array}{c}\text { Code } \\
\text { Account }\end{array}$ \\
\hline Kas & 111 \\
\hline Piutang Dagang & 112 \\
\hline Piutang Tak Tertagih & 611 \\
\hline Perlengkapan & 114 \\
\hline Peralatan & 121 \\
\hline Modal & 311 \\
\hline Dividen & 312 \\
\hline Penjualan & 411 \\
\hline
\end{tabular}

\begin{tabular}{|l|c|}
\hline \multicolumn{1}{|c|}{ Account Name } & $\begin{array}{c}\text { Code } \\
\text { Account }\end{array}$ \\
\hline Pendapatan Lain-lain & 412 \\
\hline Persediaan Bahan Baku & 115 \\
\hline Persediaan Bahan Penolong & 116 \\
\hline Beban Gaji\&Upah & 521 \\
\hline Utang Gaji & 213 \\
\hline Beban Listrik & 522 \\
\hline Beban Air & 523 \\
\hline Beban Telepon & 524 \\
\hline
\end{tabular}

B. Data Flow Diagram Yang Diusulkan

1. Diagram Konteks Yang Diusulkan

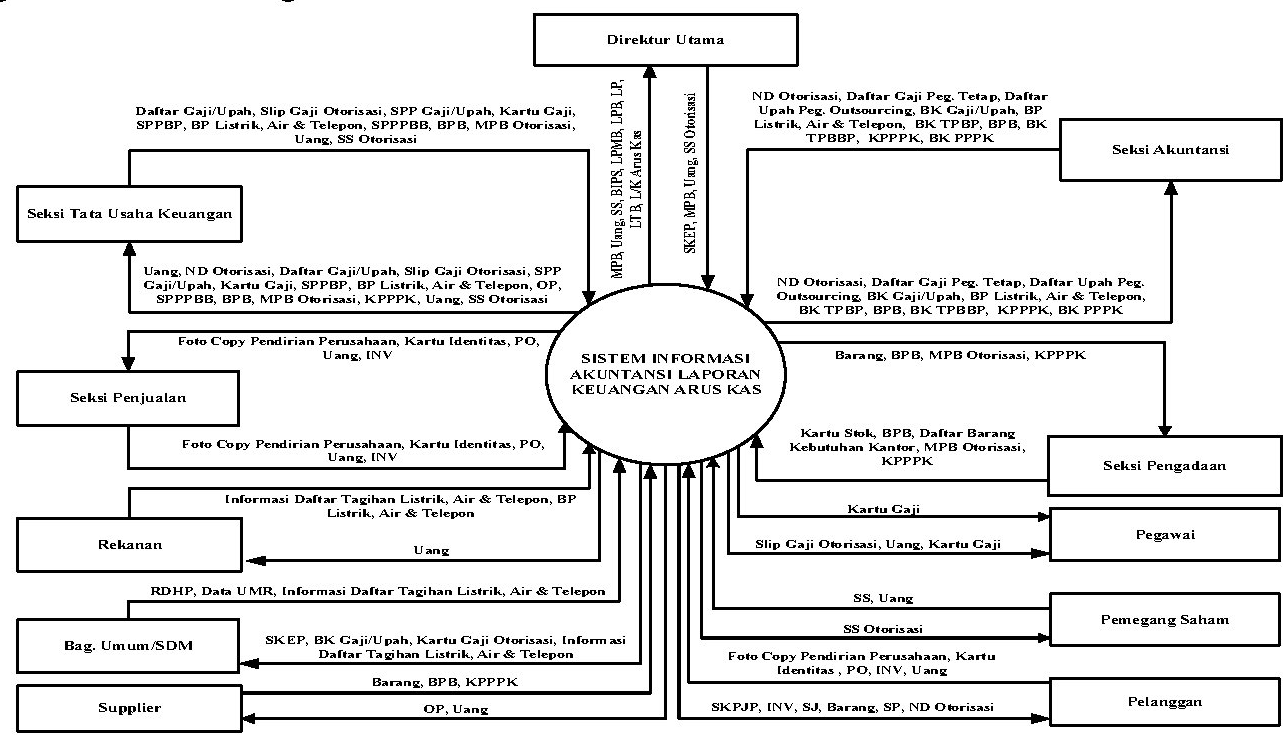

Gambar 11. Diagram Konteks Usulan

2 Data Flow Diagram Level 1 yang Diusulkan 


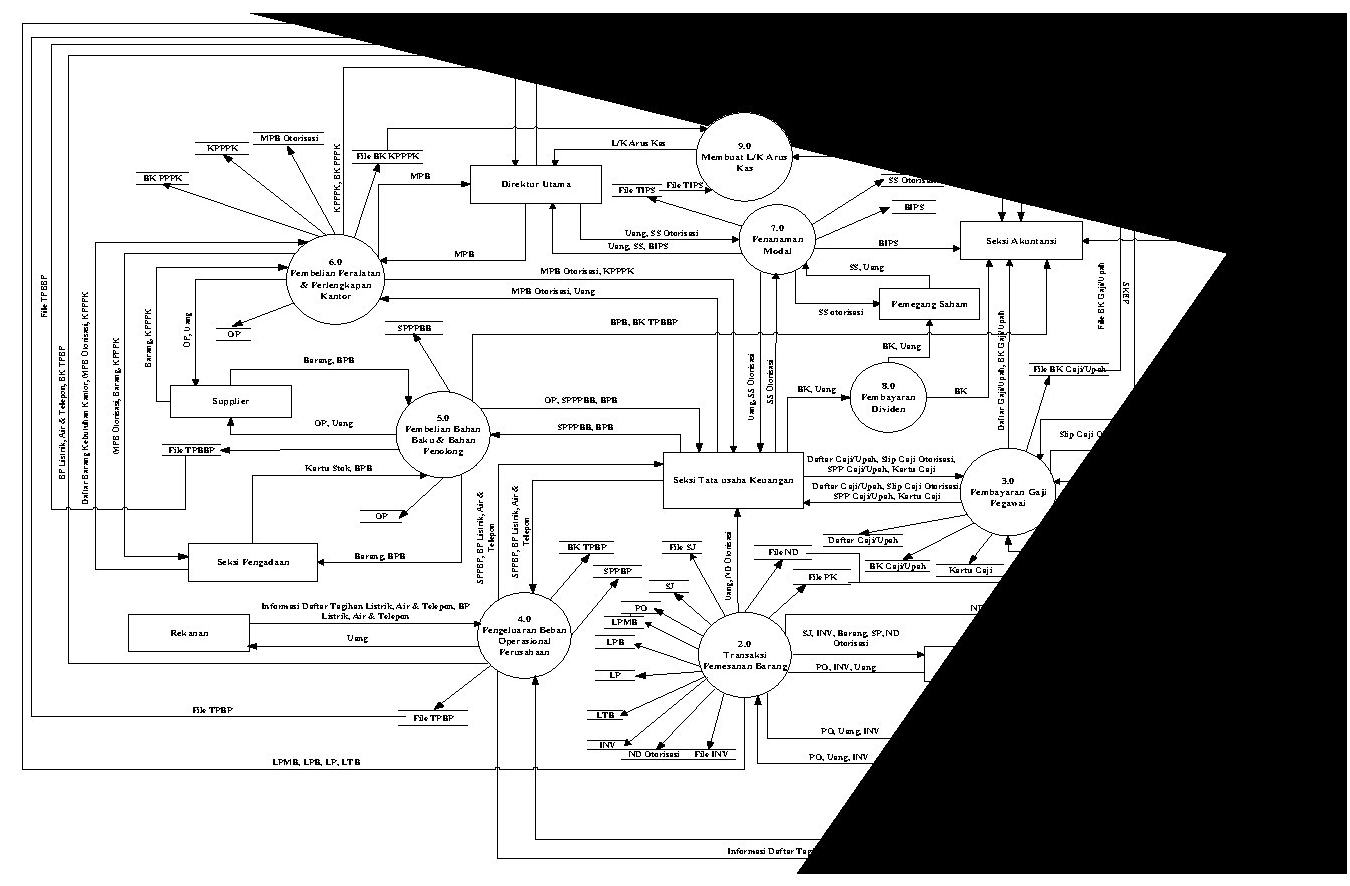

Gambar 12. Data Flow Diagram Level 0 Yang Diusulkan

C. Bagan Alir Sistem Yang diusulkan

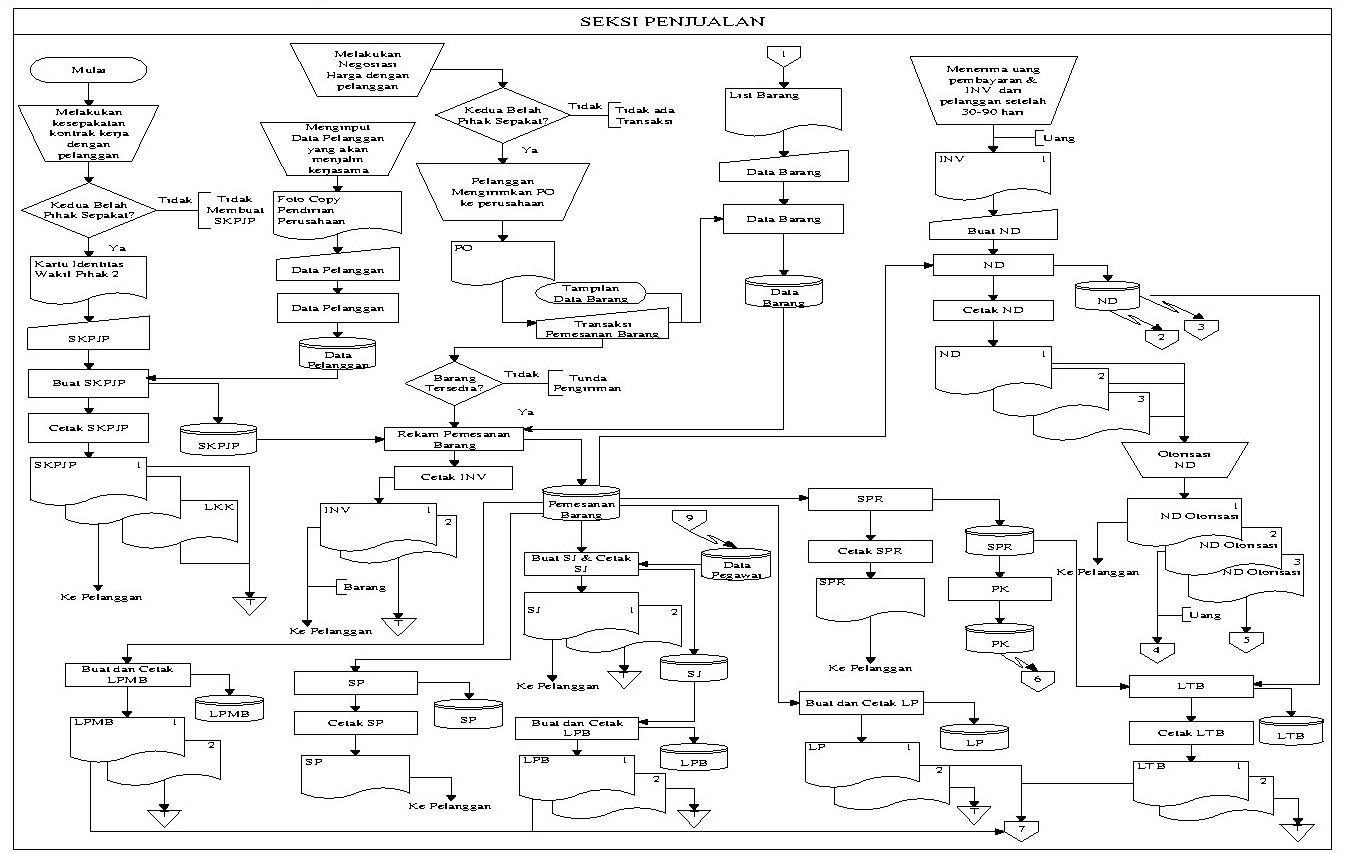

Gambar 13. Bagan Alir Sistem Usulan (1) 
Jurnal Riset Komputerisasi Akuntansi

@is The Best, Vol. 1, No. 1, April 2012: Hal. 61-80

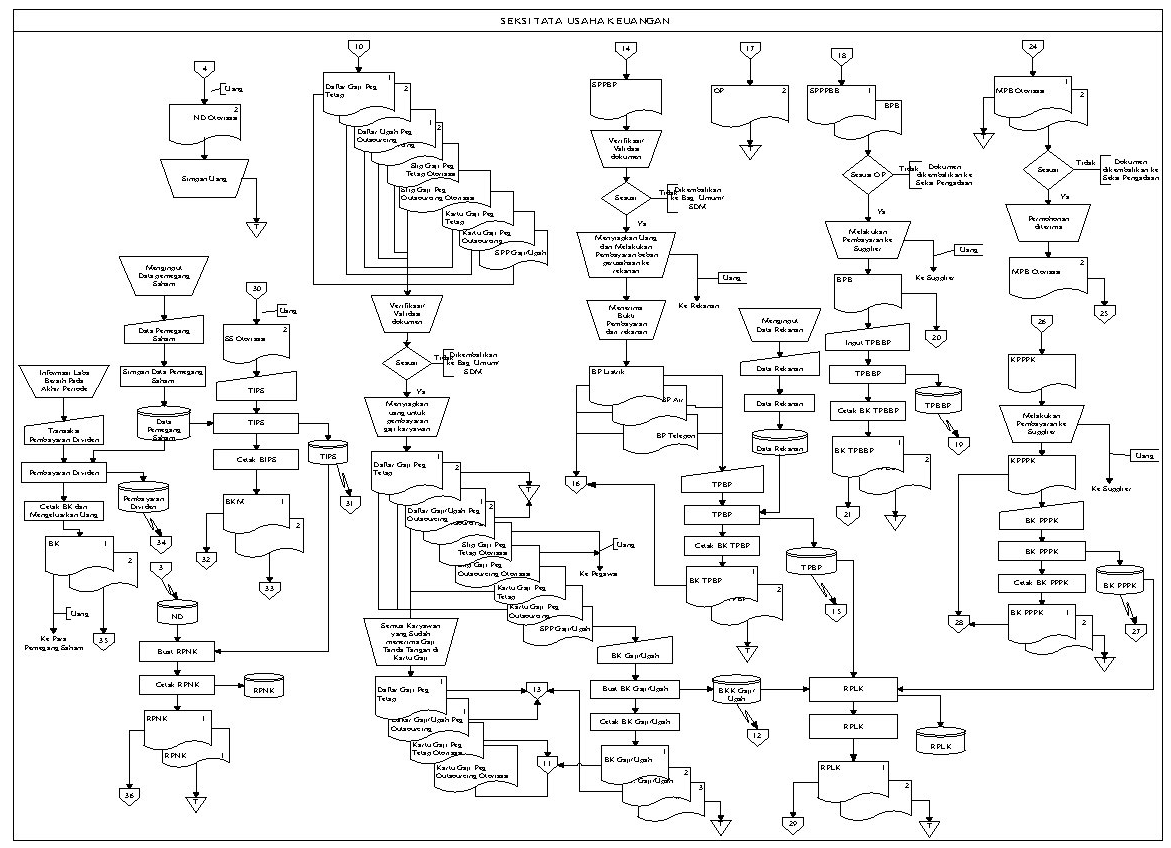

Gambar 14. Bagan Alir Sistem Usulan (2)

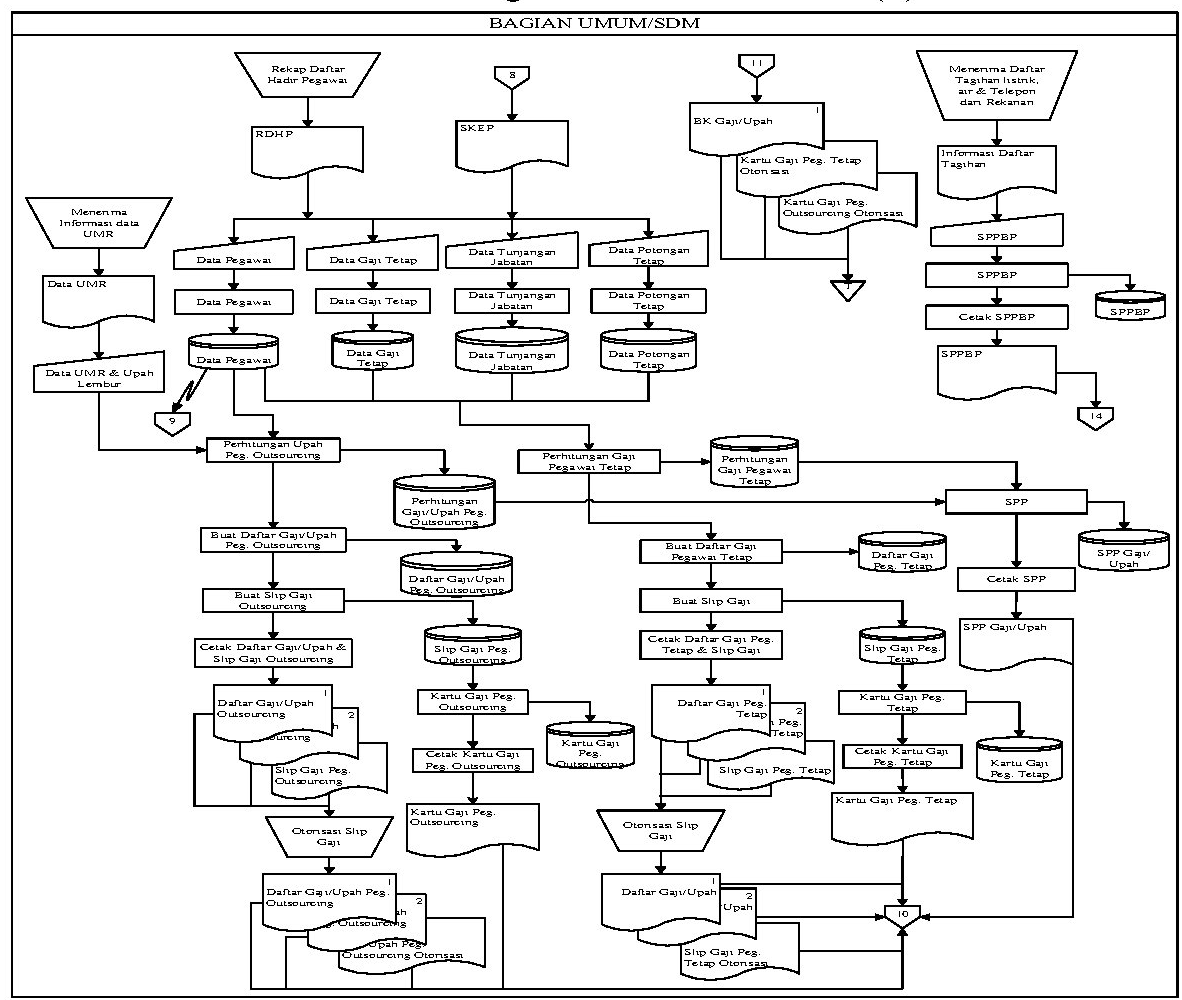

Gambar 15. Bagan Alir Sistem Usulan (3) 
Jurnal Riset Komputerisasi Akuntansi

@is The Best, Vol. 1, No. 1, April 2012: Hal. 61-80

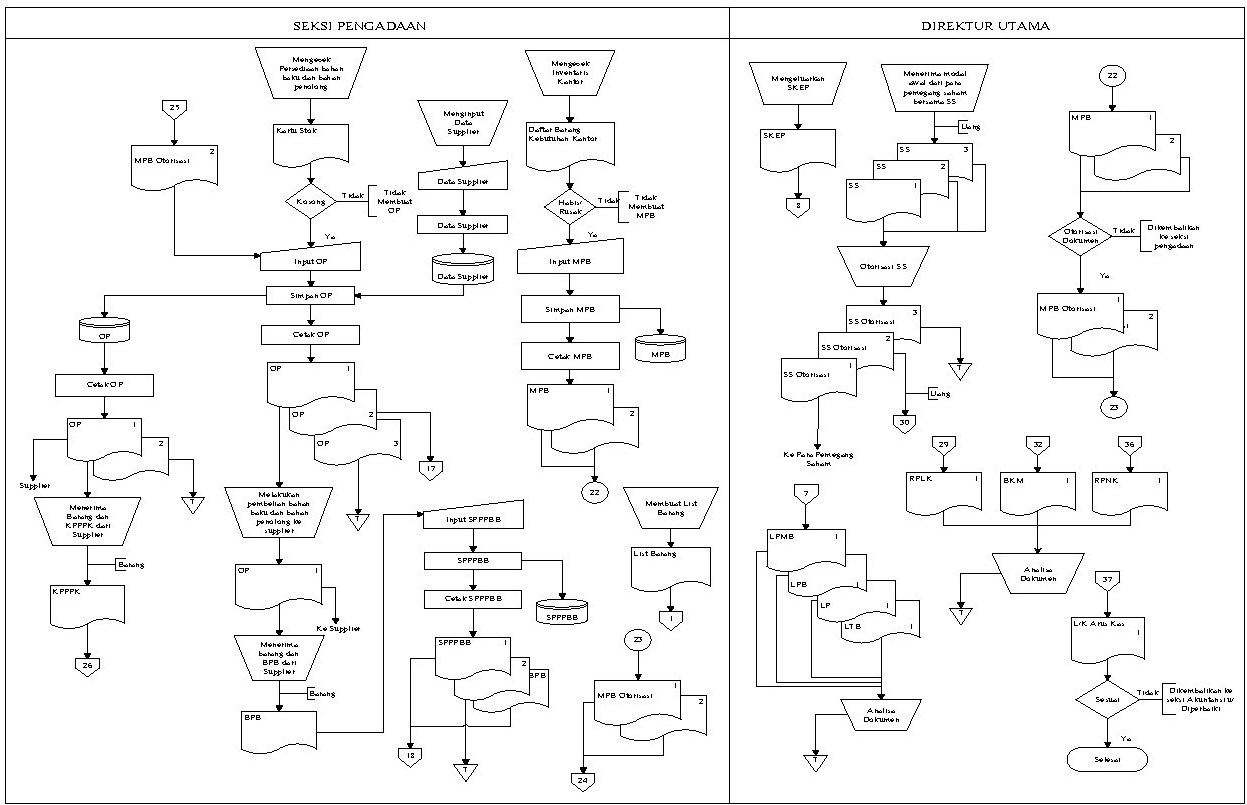

Gambar 16. Bagan Alir Sistem Usulan (4)

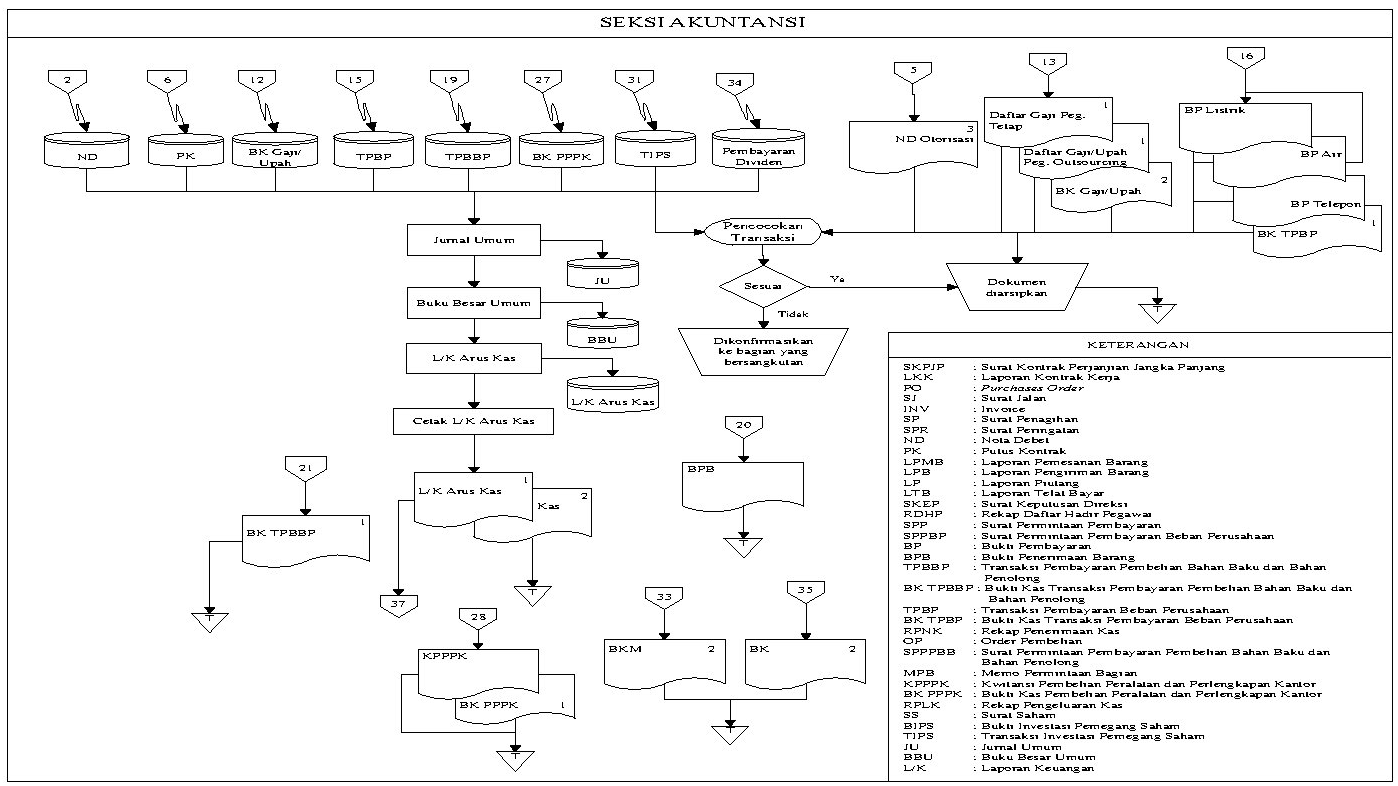

Gambar 17. Bagan Alir SistemUsulan (5)

\subsection{PerancanganStruktur Menu Program}

A. Struktur Menu Program 


\section{Jurnal Riset Komputerisasi Akuntansi}

@is The Best, Vol. 1, No. 1, April 2012: Hal. 61-80

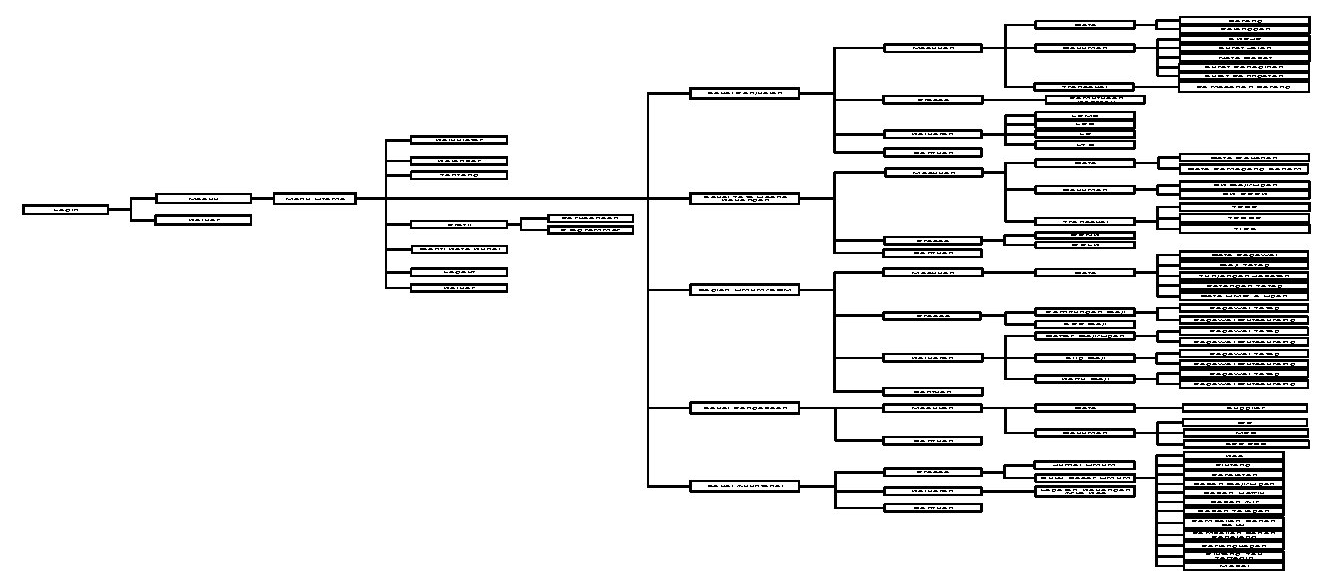

Gambar 18. Struktur Menu Program Keseluruhan

B. Tampilan Menu Program

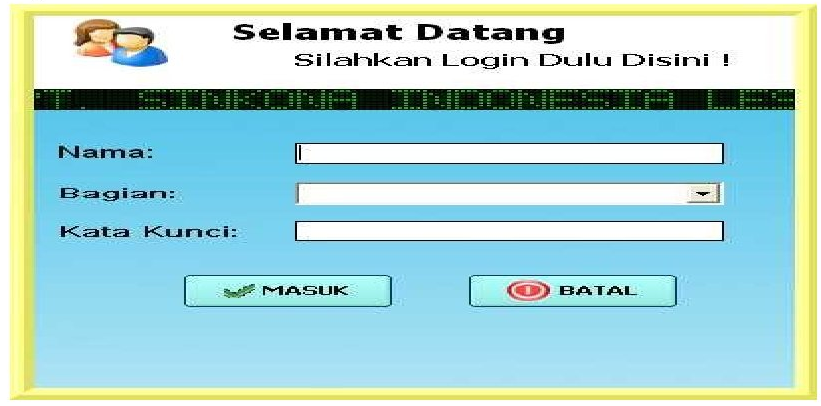

Gambar 19. Tampilan Login

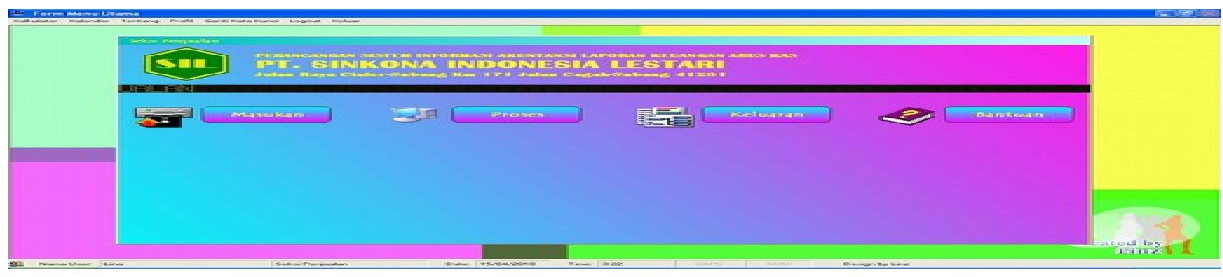

Gambar 20. Tampilan Menu Utama Seksi Penjualan

G. Tampilan Menu Program dan Report

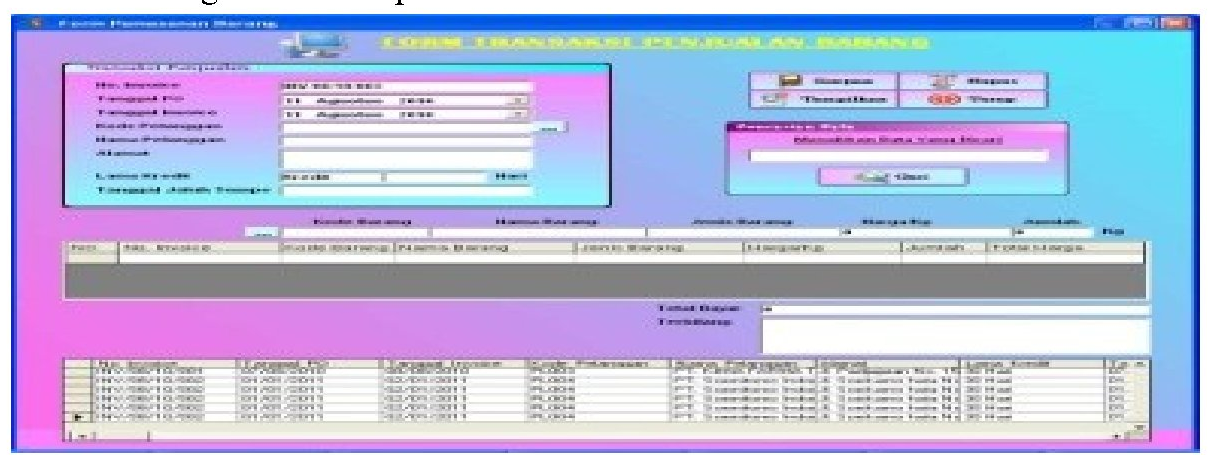

Gambar 21. Tampilan Input Transaksi Penjualan Barang 


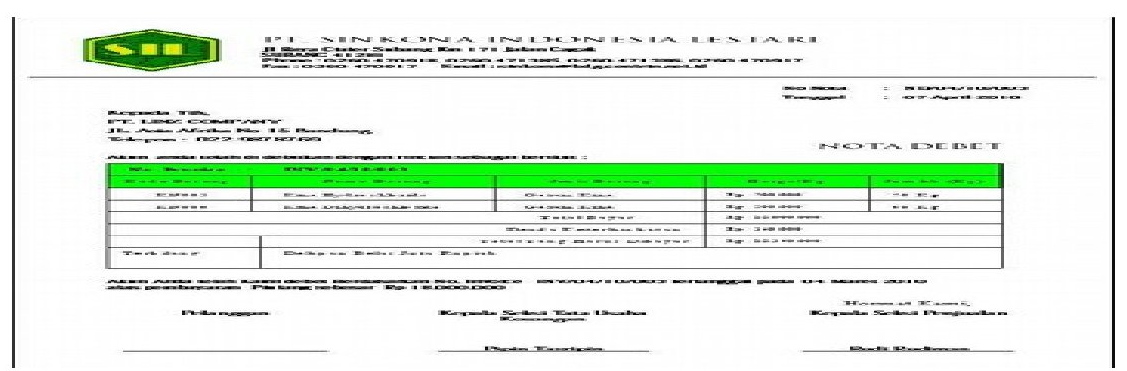

Gambar 22. Tampilan Cetakan Nota Debet

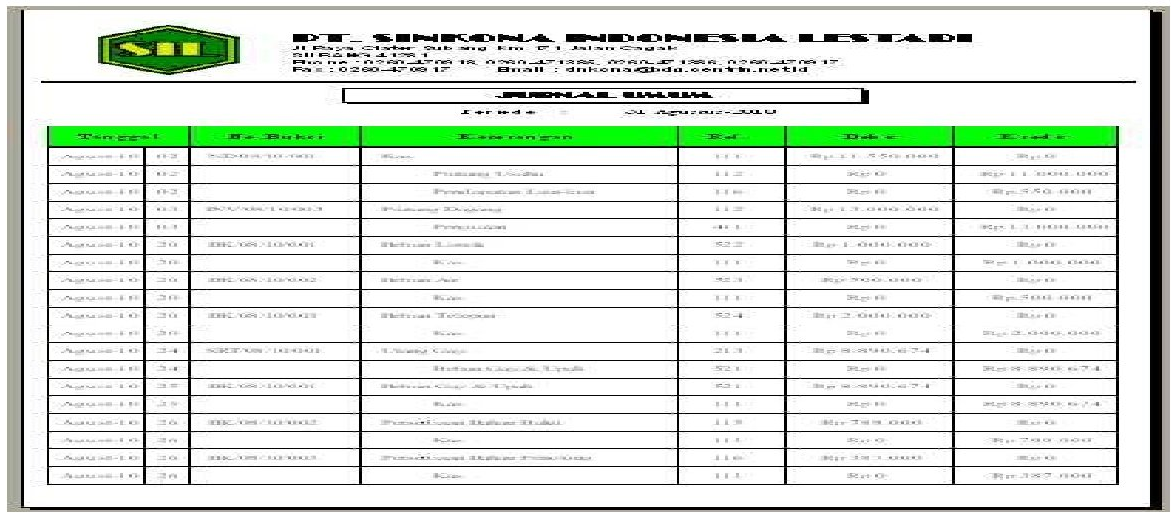

Gambar 23. Tampilan Cetakan Buku Jurnal Umum

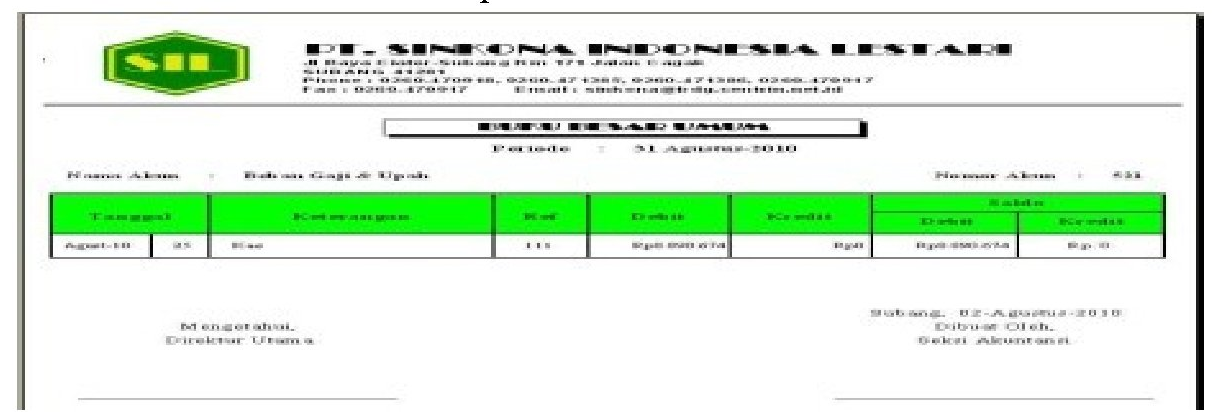

Gambar 24. Tampilan Cetakan Buku Besar Umum Beban Gaji/Upah

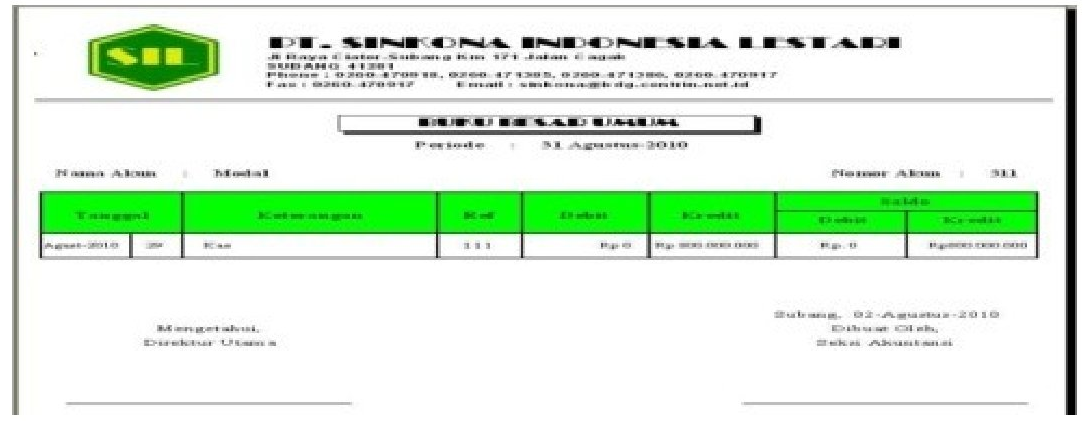

Gambar 25 Tampilan Cetakan Buku Besar Umum Modal 


\section{Jurnal Riset Komputerisasi Akuntansi}

\section{@is The Best, Vol. 1, No. 1, April 2012: Hal. 61-80}

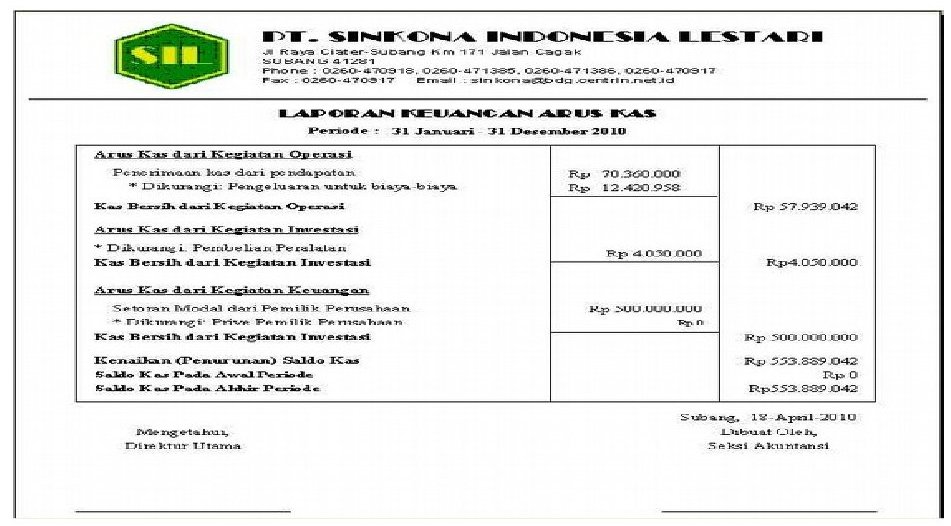

Gambar 26. Tampilan Cetakan Laporan Keuangan Arus Kas

\section{SIMPULAN DAN SARAN}

\section{Simpulan}

Setelah melakukan penelitian di PT. Sinkona Indonesia Lestari subang terutama pada bagian keuangan, akhirnya penulis mendapatkan beberapa kesimpulan yaitu:

A. Pencatatan transaksi penerimaan dan pengeluaran kas sudah menggunakan komputer tapi masih menggunakan software yang sederhana yaitu lotus sebagai media pencatatan transaksi dan alat hitung. Pencatatan akuntansinya juga belum memenuhi standar akuntansi. Transaksi dicatat dalam Jurnal Memorial, posting ke Kartu Rekening Buku besar dan proses ke Laporan Pertanggungjawaban Keuangan.

B. Penulis membuat rancangan sistem informasi akuntansi laporan keuangan arus kas berbasis client server dengan menggunakan database SQL Server 2000 dan bahasa pemrograman Microsoft Visual Basic 6.0. Tool-tool yang digunakan dalam Perancangan Sistem Informasi Akuntansi Laporan Keuangan Arus Kas yaitu Diagram Konteks, Data Flow Diagram, Bagan Alir Sistem, dan Entity Relationship Diagram. Transaksi dicatat dalam jurnal umum, posting ke buku besar umum dan keluaran yang dihasilkan berupa laporan keuangan arus kas, sehingga dapat membantu bagian seksi tata usaha keuangan danseksi akuntansi untuk mengolah data transaksi keuangan perusahaan untuk menghasilkan informasi yang dibutuhkan oleh manajemen dan pihak yang membutuhkan secara cepat dan akurat sehingga para pimpimnan dapat mengambil keputusan dengan baik dan dapat mingkatkan mutu dari pengambilan keputusan tersebut.

\section{Saran}

A. Perancangan sistem informasi akuntansi laporan keuangan arus kas berbasis client server dengan menggunakan database SQL Server 2000 dan bahasa pemrograman Microsoft VisualBasic 6.0,dapat membantu dan mempermudah dalam menginput data dan mengolah data transaksi dalam pembuatan laporan yang diserahkan ke pemakai informasi yaitu Pimpinan Perusahaan atau pihak lain yang membutuhkan seperti para pemegang saham.Apabila perusahaan akan menggunakan program aplikasi ini, maka komputer yang digunakan minimal menggunakan ProcessorIntel Pentium IV, Motherboard K7SOM+, Harddisk Minimal 40 Gb,

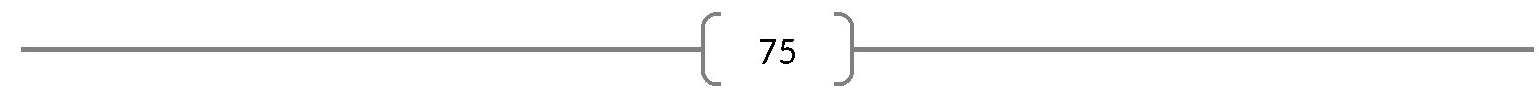




\section{Jurnal Riset Komputerisasi Akuntansi \\ @is The Best, Vol. 1, No. 1, April 2012: Hal. 61-80}

memory DDR2256 MB dan terdapat Software windows XP, Microsoft Visual Basic dan SQL Server 2000.

B. Laporan yang dihasilkan oleh sistem informasi akuntansi ini adalah laporan keuangan arus kas sehingga perlu pengembangan informasi laporan keuangan yang luas sehingga pengambilan keputusan dapat dilakukan dengan baik.

\section{DAFTAR REFERENSI}

Bastian, Indra. 2003. Sistem Akuntansi Sektor Publik. Jakarta: Salemba empat.

bin Ladjamudin, Al-bahra. 2005. Konsep Sistem BasisData dan Implementasinya. Yogyakarta: Graha Ilmu.

Bodnan, George H. Penerjemah Amir AbadiJusuf. 2000. Sistem Informasi Akuntansi. Jakarta:Salemba Empat.

Darmayuda, Ketut. 2007. Program Aplikasi Client Server. Bandung: Informatika.

Fathansyah. 2002. Basis Data. Bandung: Informatika.

Halim, Abdul. 2004. Akuntansi Sektor Publik-Akuntansi Keuangan Daerah. Jakarta: Salemba Empat

HM, Jogiyanto. 2005. Analisis dan Desain Sistem Informasi. Yogyakarta: Andi.

HM, Jogiyanto. 2000 . Pengenalan Komputer: Dasar Ilmu komputer, pemrograman, sistem informasi dan inteligensi buatan. Yogyakarta: Andi Offset.

Krismiaji. 2005. Sistem Informasi Akuntansi. Yogyakarta: Unit Penerbit dan Percetakan AMP YKPN.

Kurniadi, Adi. 2000. Pemrograman Visual Basic 6.0. Jakarta: PT Elex Media Komputindo.

Kusrini. 2007. Membangun SIA dengan Visual Basic \& Microsoft SQL Server. Yogyakarta: Andi. Nazir, M. 2005. Metode Penelitian. Jakarta: Ghalia Indonesia.

Nugroho, Adi. 2005. Analisis dan Perancangan Sistem Informasi dengan Metodologi berorientasi objek. Bandung: Informatika.

Prijana, 2005. Metode Sampling Terapan. Bandung: Humaniora

Ramadhan, Arief. 2005. SQL Server dan Visual Basic 6.0. Jakarta: Elex Media Komputindo.

Sarwono, Jonathan. 2008. Riset Bisnis. Yogyakarta: Andi

SR Soemarso. 2004. Akuntansi Suatu Pengantar Buku 1 Edisi 5. Jakarta: Salemba Empat.

Sugiyono. 2002. Metode Penelitian Bisnis (8th ed). Bandung: Alfabeta.

Susanto, Azhar. 2004. Sistem Informasi Akuntansi Konsep Dan Pengembangannya. Bandung: Lingga jaya

Sutabri, Tata. 2003. Analisa Sistem Informasi. Yogyakarta: Andi Yogyakarta.

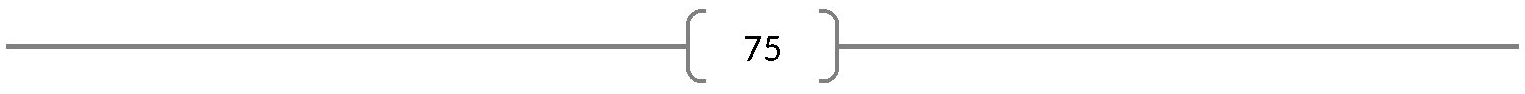




\section{PROFILPENULIS}

\section{PENULIS 1}

Nama Lengkap : Dony Waluya Firdaus

Alamat : Jln. Diapati Ukur 112-114 Bandung 40132

No Telp : : 085624268753

Email : dony_waluya@yahoo.com

\section{PENULIS 2}

Nama Lengkap : Lina Roslina

Alamat

No. HP

: Cimanglid RT22/RW03 Kasomalang- Subang 41281

Email : 085221463534

: cutelinz@rocketmail.com
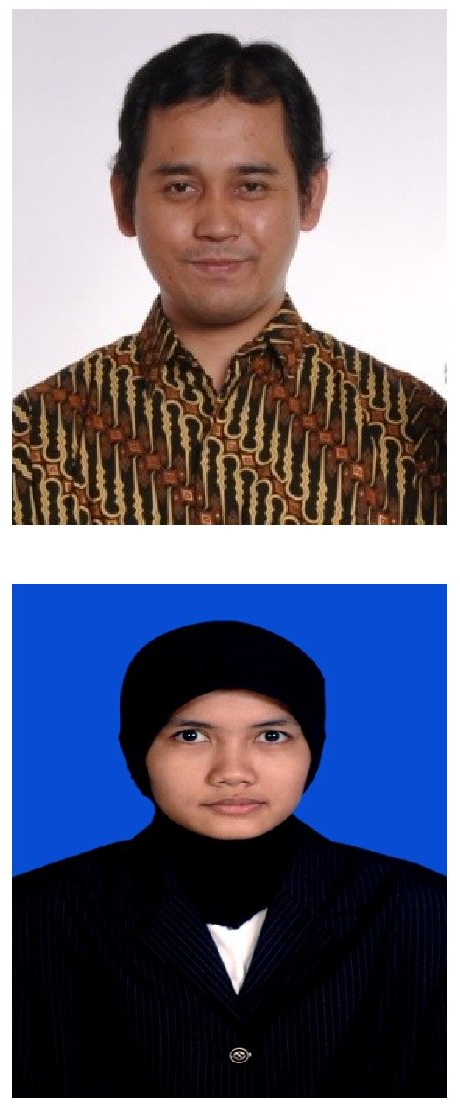

\section{PENULIS 3}

Nama Lengkap : Hery Dwi Yulianto

Alamat : Kmp Pasir Kaliki Barat No 2 Sadang Serang Kec, Coblong Bandung

No Telp : : 08382821127

Email : denderpete@yahoo.com

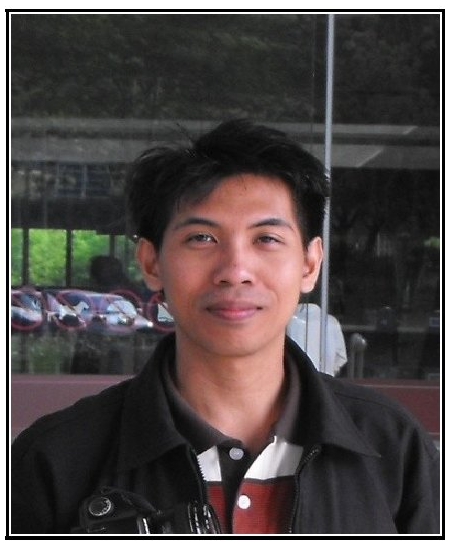

